\title{
Labour Productivity in Different Segments of Aircraft Industry
}

\author{
Leonid Sobolev ${ }^{1}$ \\ ${ }^{1}$ Moscow Aviation Institute (National Research University), Moscow, Russian Federation \\ Correspondence: Leonid Sobolev, Moscow Aviation Institute (National Research University), Moscow, 4, \\ Volokolamskoe Highway, 125993, Russian Federation. Tel: 7-963-753-7110. E-mail: sobolevLB@ yandex.ru
}

Received: April 14, 2020

Accepted: May 15, 2020

Online Published: June 18, 2020

doi:10.5430/rwe.v11n3p245

URL: https://doi.org/10.5430/rwe.v11n3p245

\begin{abstract}
This article is devoted to the problem of labor productivity (LP) in various segments of the global aircraft industry over the past decade. Intense competition forces aircraft manufacturers to pursue a policy of saving resources (primarily, workforce) at the all stages of the life cycle of aircraft and to introduce innovative technologies, automation, and robots. In assessing the relative growth of LP, the inflation (relative to the base 2009) and the purchasing power parity (PPP) of national currencies relative to the dollar are taken into account. The analysis showed that the LP is different for aircraft market segments and depends on development of market relations in the countries-manufacturers. The author believes that the main difficulty to the LP growth in countries with developing markets are monopolism, weak management, and insufficient skills of engineers, marketers, and workers.
\end{abstract}

Keywords: aviation industry, cost savings, labor productivity (LP), personnel, revenue

\section{Introduction}

LP is one of the main indicators of the competitiveness of a country and industry (Baggerly, 2017). It is obvious that in order to increase the LP, each aircraft manufacturing company should create competitive advantage, carry out structural transformations, introduce innovations, update products, and reduce production costs. The global crisis of 2008-2009 slightly affected aircraft manufacturing companies, for some time the demand for air transportation and, accordingly, orders for civilian aircraft decreased. However, after the crisis end, the demand for civilian aircraft recovered, the competition intensified even more, forcing aircraft manufacturers to seek new opportunities to increase production efficiency. This article shows that in the period 2009-2018 (relatively favorable for aircraft construction and air transportation), LP growth was fairly uniform and at a faster pace than in previous years. To a large extent, the growth of LP was facilitated by increased competition from the European company Airbus, which challenged Boeing., including on the LP issue (Tracy, 2004). The article did not include data for 2019, although it has already been published partially.

As a result of two crashes, at the end of 2018 and the beginning of 2019, the Boeing suspended the supply of 400 constructed aircraft, which dramatically changed the balance between Boeing and Airbus in the jetliner market. Nevertheless, the 2019 data will not affect the general conclusions made in the article. It is obvious that the beginning of a new global crisis associated with the COVID-19 has already caused a significant drop in demand in the air transportation market and will soon lead to a decrease in orders for aircraft. But at the end of this crisis, the demand for aircraft will recover, and people will again turn to travel around the world.

A quantitative assessment of LP in companies was calculated as the ratio of the total revenue (TR) of the company (or aviation division) to the number of employees. This data can be tracked in dynamics according to the annual reports available in the free access. This methodology is recommended by the International Labor Organization (ILO), but the author also made adjustments for inflation and PPP of national currencies.

\section{LP in the Jetliner Segment}

The production of jetliners occupies more than $60 \%$ of the aircraft market (about 170 billion dollars in 2018). In this segment, a duopoly of Boeing and Airbus has now formed, that in the future may be broken by the Russian United Aircraft Corporation (UAC) with the MS-21 project and the Commercial Aircraft Corporation of China with the C-919. Table 1 shows the data on LP depending on TR and the number of employees (E) in Airbus and Boeing for 2009-2018. 
Table 1. LP of Boeing and Airbus (2009-2018)

\begin{tabular}{lllllllllll}
\hline Indicator/Year & $\mathbf{2 0 0 9}$ & $\mathbf{2 0 1 0}$ & $\mathbf{2 0 1 1}$ & $\mathbf{2 0 1 2}$ & $\mathbf{2 0 1 3}$ & $\mathbf{2 0 1 4}$ & $\mathbf{2 0 1 5}$ & $\mathbf{2 0 1 6}$ & $\mathbf{2 0 1 7}$ & $\mathbf{2 0 1 8}$ \\
\hline Boeing & & & & & & & & & & \\
TR (billion dollars) & 67,7 & 63,8 & 68,2 & 81,7 & 86,6 & 90,8 & 96,1 & 94,6 & 93,4 & 101 \\
E (thousand) & 157 & 161 & 172 & 174 & 168 & 165 & 161 & 151 & 146 & 153 \\
LP (thousand dollars/E) & $\mathbf{4 3 1}$ & $\mathbf{3 9 7}$ & $\mathbf{3 9 7}$ & $\mathbf{4 6 9}$ & $\mathbf{5 1 4}$ & $\mathbf{5 4 8}$ & $\mathbf{5 9 6}$ & $\mathbf{6 2 8}$ & $\mathbf{6 4 5}$ & $\mathbf{6 6 1}$ \\
Airbus & & & & & & & & & & \\
TR (billion euros) & 40,5 & 43,6 & 46,3 & 49,4 & 52,6 & 55,3 & 58,9 & 61,1 & 59,0 & 63,7 \\
E (thousand) & 119 & 121 & 127 & 137 & 139 & 139 & 138 & 135 & 129 & 134 \\
LP (thousand euros/E) & $\mathbf{3 4 0}$ & $\mathbf{3 6 2}$ & $\mathbf{3 6 3}$ & $\mathbf{3 6 1}$ & $\mathbf{3 7 7}$ & $\mathbf{3 9 9}$ & $\mathbf{4 2 8}$ & $\mathbf{4 5 2}$ & $\mathbf{4 5 6}$ & $\mathbf{4 7 6}$ \\
\hline
\end{tabular}

Source: Annual Reports of Boeing and Airbus

Table 1 shows that over the past decade the TR and LP in both companies have been constantly increased. The LP at Airbus exceeded 500000 dollars/E, while at Boeing it exceeded 660000 dollars/E. The LP increased on about 35\% or an average on 3.5\% with considering inflation (1.5-2.0\% per year). In CCAA (2018) it is shown that in 1972-1991 the average LP growth in the civilian aircraft industry was 3.2\%, and during this period the growth was quite uneven. The main drivers of sales growth (and, accordingly, TR) in the segment of jetliner aircraft market were the steady increasing demand for international and inter-regional flights (about 5-6\% per year) and a reduction in the life of liners to 25 years (Aerospace Trends and New Technology Developments, 2018; IATA, 2018).

Part of the planes before the end of its life is converted into cargo aircraft. The number of employees in both companies at the beginning of the decade increased slightly, and then almost stabilized with the outstripping growth in revenue, as additional methods of reducing costs were used (Kirsch, 2018).

Both companies relatively painlessly (compared, for example, with the automotive industry) survived the crisis of 2008-2009. During the crisis years, the number of orders decreased, but both companies had stock of orders for 4-5 years. In the same year, Boeing was shocked by the strike of some company's employees, demanding higher salaries and layoffs, which lasted 58 days and brought billions in losses. Boeing's management made the necessary conclusions, and over the past decade, all disagreements between the company's management and employees were settled through negotiations and mutual concessions. Airbus has avoided such disruptions through correct social policies and other ways to reduce costs. At the beginning of decade both companies carried out the large-scale restructuring, provided the positive results. In general, we can conclude that the growth of LP due to a constant increasing revenue with a relatively stable number of employees.

As the short-term measures to reduce costs, we can note the elimination of duplicate structures, a decrease in the number of the all levels' suppliers, the sale of low-efficient production assets, and the reduction of personnel not engaged in basic production operations. An effective way to reduce the costs of finalist companies and their suppliers at various levels was to optimize the value chains of the final product due to better coordination with suppliers that allows increasing LP up to $15 \%$ without increasing personnel.

In the long run, the revenue growth for both companies was facilitated by the modernization of the product line both in the narrow-body segment (B737 MAX, A320Neo) and in the wide-body segment (B-787, B-777X, A350XWB). In addition, Airbus expanded its line of narrow-body planes with relatively low-capacity aircraft segment (100-140 p/m), buying in 2018 51\% of the CSeris Bombardier division. New aircraft under the brand A-220 are in good demand (Airbus and Bombardier Announce C Series Partnership, 2017). In 2018, Airbus assembled and delivered 800 planes to customers (an increase of 11\%), setting a record for both the number of aircraft delivered and the revenue received. Boeing delivered 806 planes to customers and also achieved record revenues (more than 100 billion dollars), did not lag behind.

Due to the growth of the global fleet of aircraft of both companies, after-sales service brings more and more income. So, in 2018, the contribution of the new Boeing (Global Services) division, engaged in the maintenance and repair of the company's aircraft, amounted to more than 10 billion dollars (an increase of 17\% compared to 2017). More attention is devoted to the quality of components and the final assembly that have a direct impact on revenue growth, and, consequently, LP. Both companies have the same catalog prices for their products and slightly increasing prices for new models (usually within 10-15\%). At the same time, companies claim to increase the economic efficiency of new planes by about $15 \%$ that allows the carriers to quickly recover the additional costs of acquiring aircraft with 
new engines and new avionics and contributes to the further growth in popularity of new aircraft families. Additionally it remains possibility to upgrade previous models and convert the passenger plane into cargo one.

The aviation industry has relatively low production volumes, durable and complex assembly operations. In addition, composite materials, which are more used in the aviation industry, are difficult to automate. Both companies have created robotic departments engaged in the creation of robots to automate the assembly processes of aircraft. Automation of assembly processes and use of the lean manufacturing principle allows both companies to ensure the supply growth, practically without increasing the number of employees.

\section{LP in the Regional and Business Segments}

Three companies dominate in the regional aviation segment: Bombardier, Embraer, and Avions de Transport Régional. There is a detailed report devoted to the state of the labor market in the aerospace industry of Canada in 2017 (Kronemer \& Henneberger, 1993). The market for regional aircraft (excluding small aircraft) is relatively small: about $8 \%$ of the jetliner market. This fact explains the desire of regional aircraft manufacturing leaders (Embraer and Bombardier) to "fit" into the narrow-body aircraft segment with their new CSeries and ERJ-E2 projects - competitors of the B-737 and A-320 families. As it was mentioned above, Airbus bought 50\% shares of CSeries division and the new aircraft is now sold under the A-220 brand. And Boeing in 2019 created a joint venture with Embraer to promote the E2 series aircraft. The revenue and market share of the main manufacturers of regional and business aircraft (2017) are shown in Table 2.

Table 2. Largest companies-manufacturers of regional and business aviation (2017)

\begin{tabular}{lllllll}
\hline № & Company / Division & $\begin{array}{l}\text { Revenue of Region } \\
\text { aircraft, billion dollars }\end{array}$ & Market share, \% & $\begin{array}{l}\text { Revenue of Business } \\
\text { aircraft, billion dollars }\end{array}$ & $\begin{array}{l}\text { Market } \\
\text { share, \% }\end{array}$ \\
\hline 1 & Embraer & 2.8 & 34 & 0.92 & 6.7 \\
2 & $\begin{array}{l}\text { Bombardier } \\
\text { Avions de Transport } \\
\text { Régional }\end{array}$ & 2.9 & 35 & 5.0 & 36.1 \\
4 & 1.8 & 22 & - & 33.9 \\
5 & $\begin{array}{l}\text { Textron Aviation } \\
\text { Dassault- Falkon }\end{array}$ & - & & 4.69 & 23.3 \\
6 & $\begin{array}{l}\text { Sukhoi Civil } \\
\text { Aircraft Company } \\
\text { (UAC) }\end{array}$ & $0.7^{*}$ & & 3.22 & - \\
Total & 8.3 & 9 & - & 100 \\
\hline
\end{tabular}

Source: Annual Reports of companies (2017)

Note: * Official data on a regional aircraft sales in the UAC annual report for 2017 (www.uacrussia.ru) are not present, therefore the estimation is given by the author on the basis of SSJ100'sales.

As follows from Table 2, the number of manufacturers in the regional and business aircraft market is greater than in the jetliner market that can be explained by a lower barrier to entry into the market and lower capital intensity of the development, manufacturing and production of such aircraft. Table 2 did not include the the Commercial Aircraft Corporation of China with its ARJ-21 and the Japanese Mitsubishi with Mitsubishi Regional Jet, just entering to the regional aircraft market. For the consumers' convenience, manufacturing companies usually offer a line of models of various passenger capacities and various configurations (engine type, one- or two-class saloon, avionics, and comfort level). Regional planes differ in the type of aircraft engines: turboprops and jet that have different flight speeds and require different length and quality of the runway.

The analysis of the market have shown that LP in regional and business aviation companies is slightly lower (10-15\%) than in the jetliner market (460-480 dollars/E) in developed economies (United States of America (USA), Canada, European Union (EU)). The LP of Embraer (Brazil) approaches this indicator only taking into account PPP. In the Russian company Sukhoi Civil Aircraft Company, even taking into account PPP, the LP is more than 2 times lower (Government Analytical Center of RF, 2017).

There are the additional differences between the regional and business aircraft market from the jetliner market: firstly, significantly smaller volume of this market; secondly, regional aviation in large western countries (USA, Canada, 
Australia, EU) has an additional competitor in the form of a developed network of high-speed roads and railways; thirdly, regional and business aircraft markets are volatile, i.e. sales may vary from year to year in quantity and in the type of aircraft ordered; fourthy, large air carriers create regional aviation units or form a network structure with independent regional air carriers to transport air passengers to large hubs. This organization of air transportation can increase the occupancy rate of seats for jetliner aircraft and compensate the losses of many regional flights.

Due to sales' volatility, the largest manufacturers of regional aircraft diversify their business. So, in addition to the aviation business, Bombardier has a transportation division that provides at least the half of the company's revenue. The aviation division, in turn, is divided into three parts: business aircraft, regional aircraft and Maintenance, Repair and Overhaul (MRO) division.

Embraer, Brazilian regional aircraft manufacturer, is diversifying its activity with business aviation and military aviation divisions. However, unlike Bombardier, Embraer has the main revenue from regional aircraft sales. Dassault Aviation also has civilian (Falkon) and military aviation divisions. Textron is a conglomerate that, in addition to a strong business aviation division, has several more businesses.

In addition, there is also a fairly large (by the number of manufacturing companies) General Aviation (GA) market, including commercial low-passenger aircraft and various types of niche aircraft (training, medical, patrol, agricultural, etc.). Usually, these GA manufacturing companies offer a line of aircraft with various types of aircraft engines and various passenger capacities. Only in the USA, GA, in total, supported 1.2 million jobs and 247 billion dollars in revenue. GE also generated 77 billion dollars in labor income (including wages, salaries, benefits, and proprietors' income) and contributed 128 billion dollars to USA Gross Domestic Product (GDP) (PwC, 2018). At the national level, each direct job in GE industry supported 3.3 jobs elsewhere in the economy. All GA aircraft are certified in the USA and Europe. There are relatively many GA companies in Europe, and they are mainly oriented to the North American and Asian markets, since the European market is limited.

Pilatus Aircraft is a popular Swiss manufacturer of the GA aircraft. The most successful company model is the Pilatus PC-12 family. These aircraft are designed for passenger and VIP transportation (PC-24), as well as for the delivery of passengers and goods on local airlines. In addition, its can be used as a patrol aircraft. The plane accommodates up to 8 people in the VIP version and 9 people in the passenger version. The main advantage is the relative low cost of maintenance and the ability to work on short unpaved runways. Since October 1994, more than 1500 aircraft of this type have been produced that operated around the world. The company's sales in 2018 is more than 1 billion dollars, the number of employees is 2283 people, the LP is 438000 dollars/E, that corresponds to regional and business aviation manufacturing companies. Every year, Pilatus Aircraft sells about 100 aircraft to customers, and supplies are usually distributed evenly between civilian and military customers.

Diamond Aircraft Industries (DAI), Austrian private manufacturer of the GA aircraft, produce six models of light and medium GA aircraft, two of which are under active development and certification. Double DA20 is a training aircraft made of composite materials with an engine of $125 \mathrm{hp}$. It is used for private flights and as a training plane for military pilots. DA40 XLS is a four-seat aircraft made of composite materials with an engine of $180 \mathrm{hp}$. DA42 is a twin-engine four-seat plane suitable for long-distance flights, one of the most technologically advanced twin-engine aircraft today. In December, 2017 DAI was acquired by the Chinese company Wanfeng Aviation.

Aircraft Industries, Czech aircraft GA manufacturing company develops, manufactures and sells popular L 410, 19-seat twin turboprop. In 2008 Aircraft Industries was acquired by Russian Ural Mining and Metallurgical Company (UGMK). Currently, UGMK is building a plant for the production of L-410NG in Russia. By acquiring small western companies, China and Russia gain access to the Western technologies and markets.

\section{LP in the Military Aviation Segment}

The military segment of the aviation market occupies about $30 \%$ of total sales, and this share has significantly decreased over the past decade (Fedorovich, Muravnik \& Bochkarev, 2013; Sobolev, 2019). The largest military aircraft contractor in the USA, Lockheed Martin (LM), dominates in the military segment of the aircraft manufacturing industry, while Boeing, Airbus, Dassault Aviation, Eurofighter, SAAB, and the Russian company UAC are competitors in the military aviation market in various segments. Data on changes in LP in the "military" companies Lockheed Martin (LM), Dassault Aviation (DA), and UAC are summarized in Table 3. 
Table 3. LP in LM and DA (2009-2018)

\begin{tabular}{llllllllllll}
\hline Indicator/Year & $\mathbf{2 0 0 9}$ & $\mathbf{2 0 1 0}$ & $\mathbf{2 0 1 1}$ & $\mathbf{2 0 1 2}$ & $\mathbf{2 0 1 3}$ & $\mathbf{2 0 1 4}$ & $\mathbf{2 0 1 5}$ & $\mathbf{2 0 1 6}$ & $\mathbf{2 0 1 7}$ & $\mathbf{2 0 1 8}$ \\
\hline $\mathbf{L M}$ & & & & & & & & & & \\
TR (billion dollars) & 44.0 & 45.8 & 46.5 & 47.2 & 45.4 & 45.6 & 46.1 & 47.3 & 51.1 & 53.8 \\
E (thousand) & 140 & 132 & 123 & 120 & 115 & 112 & 126 & 97 & 100 & 102.5 \\
$\begin{array}{l}\text { LP (thousand dollars/E) } \\
\text { Dassault Aviation }\end{array}$ & $\mathbf{3 1 4}$ & $\mathbf{3 5 0}$ & $\mathbf{3 7 8}$ & $\mathbf{3 9 3}$ & $\mathbf{4 0 1}$ & $\mathbf{4 0 7}$ & $\mathbf{3 6 6}$ & $\mathbf{4 8 7}$ & $\mathbf{5 1 1}$ & $\mathbf{5 2 5}$ \\
TR (billion dollars) & & & & & & & & & & \\
E (thousand) & 2.8 & 3.6 & 2,9 & 3,3 & 4,0 & 3.2 & 3.3 & 3.2 & 4.2 & 4.4 \\
LP (thousand dollars/E) & 12.0 & 11.6 & 11.5 & 11.5 & 11.6 & 11.7 & 11.9 & 12.0 & 11.7 & 11.5 \\
UAC & $\mathbf{2 2 8}$ & $\mathbf{3 0 7}$ & $\mathbf{2 5 4}$ & $\mathbf{2 9 0}$ & $\mathbf{3 4 2}$ & $\mathbf{2 7 4}$ & $\mathbf{2 7 8}$ & $\mathbf{2 6 2}$ & $\mathbf{3 5 8}$ & $\mathbf{3 8 4}$ \\
TR (billion roubles) & & & & & & & & & & \\
E (thousand) & 99 & 141 & 162 & 171 & 220 & 295 & 352 & 417 & 452 & - \\
LP (thousand roubles/E) & 1011 & 1470 & 1749 & 1857 & 2353 & 2986 & 3471 & 4013 & 4391 & - \\
\hline
\end{tabular}

Source: Annual Reports of LM, DA, and UAC.

As follows from Table 3, the growth in LP at LM and DA over the past decade was the same as at the civil segment (1.5 times). The revenue from military products consistently was equal about $80 \%$ of LM's TR, but the company does not produce civilian aircraft. Stable income growth for LM was achieved due to sales growth of the latest F-35 multi-functional combat plane and deep diversification of the company's products (rocketry, Sikorsky helicopters, military and civilian electronics). Starting in 2011, F-35 shipments increased 10 times and in 2018 amounted to 91 planes, of which 37 were exported. In 2011, LM is recognized as the most successful company in the USA in introducing lean production technology. The personnel are constantly decreasing (Table 3), only slightly increasing over the past two years (New Aircraft Deliveries, 2019). The problems of the labor market in the American military aircraft industry are considered in Deloitte (2017).

In general, LP in military aviation contractors has the same order as in companies with a predominance of civilian products. Hence the similar official salary level is the same as in the "civilian" companies (average annual salary in LM is 78000 dollars, in DA is 91000 dollars). Difference in average salary level may be due to different calculation methods, location of production sites and other factors. As follows from the Table 3, LP in UAC for the period from 2009 to 2017 increased nominally 5 times, however, this growth began from a very low position and in recent years it practically stopped. Taken into account the inflation and the depreciation of the ruble against Western currencies, the LP growth in the UAC over the past decade has decreased to $18 \%$.

The great importance to all world manufacturers of civilian and military aircraft is export. At the largest air shows in 2017 (Le Bourget-2017, Dubai-2017), Boeing and Airbus signed contracts for 75 billion dollars and 40 billion dollars, respectively.

\section{Conclusions}

1. In the largest aircraft manufacturing companies in the world (Boeing and Airbus), with military and civilian segments, the increase in LP is a consequence of the growth in sales of civilian planes and a set of methods to increase production efficiency (modernization of the product line, lean manufacturing, automation and robotics, optimization of component supplies all levels, etc.) in both segments.

2. LP in regional, business, and GA aircraft markets is just a little lower of the LP in the jetliner aircraft market due to high competition that will increase in the coming years due to the entry of new companies from China, Russia, and Japan.

3. Companies with predominantly military products (Lockheed Martin, Dassault Aviation) use the same methods as "civilian" corporations, plus the export orientation and "motivating" (cost-plus-incentive fee (CPIF)) contracts from government customers, to increase revenue (Sobolev, 2018).

4. Comparing UAC with similar Western companies, it becomes obvious that monopolism in production and monopsony in the labor market are a hindrance to the growth of LP in this company. 


\section{References}

Aerospace Trends and New Technology Developments. (2018). Retrieved from https://ewi.org/wp-content/uploads/2018/12/16_5_18_Aerospace_Trends_eBook_FINAL.pdf

Airbus and Bombardier Announce C Series Partnership. (2017). Retrieved from https://www.airbus.com/newsroom/press-releases/en/2017/10/airbus-bombardier-cseries-agreement.html

Baggerly, D. (2017). Productivity and efficiency remain key challenges for the aerospace industry. The 16th Annual Pacific Northwest Aerospace Alliance (PNAA). Retrieved from https://www.supplyon.com/en/blog/productivity-efficiency-remain-key-challenges-aerospace-industry/

CCAA. (2018). Labour Market (in Canada) Aviation and Aerospace Industries. March 2018. Retrieved from https://www.avaerocouncil.ca/sites/default/files/files/ccaa_lmi_report_march_2018_-_final.pdf

Deloitte. (2017). US aerospace and defense sector export and labor market study. Retrieved from https://www2.deloitte.com/content/dam/Deloitte/us/Documents/manufacturing/us-2017-us-A\&D-exports-and-la bor-market-study.pdf

Fedorovich, V., Muravnik, V., \& Bochkarev, O. (2013). The USA: military economy (organization and management). International Relations, 344.

Government Analytical Center of RF. (2017). Labour Productivity in the Russian Federation. Social bulletin of RF Government Analytical Center, 9, 25-40.

IATA. (2018). World Air Transport Statistics (WATS). Retrieved from http://www.iata.org/pressroom/pdf

Kirsch, J. (2018). The new value chain - Greater efficiency in the aviation industry. Retrieved from https://www.aircraftinteriorsinternational.com/features/the-new-value-chain-a-greater-efficiency-in-the-aviation -industry.html

Kronemer, A., \& Henneberger, J. E. (1993). Productivity in aircraft manufacturing. Monthly Labor Review, 6, 24-33.

New Aircraft Deliveries. (2019). Retrieved from https://www.planespotters.net/special/deliveries-2019

PwC. (2018). Contribution of General Aviation to the US Economy in 2018. Retrieved from www.pwc.com/us/nes

Sobolev, L. (2018). Economic Aspects of Military Aircraft Engineering. Economic Analysis: Theory and Practice, 17(4), 600-613.

Sobolev, L. (2019). Strategies for the Development of Aerospace Corporations. National Interests: Priorities and Security, 15(1), 4-17.

Tracy, J. (2004). 9 Drivers and Challenges for U.S. Aerospace Manufacturing. In New Directions in Manufacturing: Report of a Workshop. Washington, DC: The National Academies Press. 